\title{
Early school-leaving in the Netherlands : the role of student-, family- and school factors for early school- leaving in lower secondary education
}

Citation for published version (APA):

Traag, T., \& van der Velden, R. K. W. (2008). Early school-leaving in the Netherlands : the role of student, family- and school factors for early school-leaving in lower secondary education. Researchcentrum voor Onderwijs en Arbeidsmarkt, Faculteit der Economische Wetenschappen. ROA Research Memoranda No. 3 https://doi.org/10.26481/umaror.2008003

Document status and date:

Published: 01/01/2008

DOI:

10.26481/umaror.2008003

Document Version:

Publisher's PDF, also known as Version of record

Please check the document version of this publication:

- A submitted manuscript is the version of the article upon submission and before peer-review. There can be important differences between the submitted version and the official published version of record.

People interested in the research are advised to contact the author for the final version of the publication, or visit the DOI to the publisher's website.

- The final author version and the galley proof are versions of the publication after peer review.

- The final published version features the final layout of the paper including the volume, issue and page numbers.

Link to publication

\footnotetext{
General rights rights.

- You may freely distribute the URL identifying the publication in the public portal. please follow below link for the End User Agreement:

www.umlib.nl/taverne-license

Take down policy

If you believe that this document breaches copyright please contact us at:

repository@maastrichtuniversity.nl

providing details and we will investigate your claim.
}

Copyright and moral rights for the publications made accessible in the public portal are retained by the authors and/or other copyright owners and it is a condition of accessing publications that users recognise and abide by the legal requirements associated with these

- Users may download and print one copy of any publication from the public portal for the purpose of private study or research.

- You may not further distribute the material or use it for any profit-making activity or commercial gain

If the publication is distributed under the terms of Article $25 \mathrm{fa}$ of the Dutch Copyright Act, indicated by the "Taverne" license above, 


\section{Early school-leaving in the Netherlands}

The role of student-, family-and school factors for early school-leaving in lower secondary education

Tanja Traag

Rolf K.W. van der Velden

ROA-RM-2008/3

March 08

Research Centre for Education and the Labour Market

P.O. Box 616

6200 MD Maastricht

The Netherlands

E-mail: $\quad$ secretary@roa.unimaas.nl

Internet: $\quad$ www.roa.unimaas.nl

Maastricht University

Faculty of Economics and Business Administration 
The ROA Research Memorandum Series was created in order to make research results available for discussion, before those results are submitted for publication in journals.

Sec08.026.pdf 
ROA-RM-2008/3 » http://www.roa.unimaas.nl/resmem.htm

\section{Abstract}

\section{Early school-leaving in the Netherlands}

The role of student-, family- and school factors for early school-leaving in lower secondary education

Most studies on early school-leaving address only partial causes of why some students leave school early. This study aims to develop a more elaborate model to explain early school-leaving in lower secondary education, taking into account individual, family and school factors at the same time. By using a longitudinal dataset we are able to attribute clear causal relations between the different factors. We distinguish four groups of school-leavers, separating 'dropouts' (those without any qualification) from those who left school after attaining a diploma in lower secondary education ('low qualified'), those who pursued education as an apprentice ('apprentices') and the ones who continued education and received a full upper secondary qualification ('full qualification). Discerning these four groups shows clear differences in the background of different types of early schoolleavers and in the effects of school factors.

Tanja Traag

Statistics Netherlands

P.O. Box 4481

$6401 \mathrm{CZ}$ Heerlen

The Netherlands

ttrg@cbs.nl
Rolf K.W. van der Velden

ROA

P.O. Box 616

6200 MD Maastricht

The Netherlands

r.vandervelden@roa.unimaas.nl 



\section{Introduction}

Early school-leaving has increasingly become of interest to both policymakers and researchers during the past decades. Early school-leaving is especially high among students from families of low socio-economic status and ethnic minorities, leading policymakers to combat early school-leaving as a means of generating equality and social integration. Moreover growing concerns for the provision of sufficiently skilled workers increased the number of policies that were taken to combat early school-leaving. In 2000, 15.5 percent of all Dutch 18-to-24-year-olds was considered an early school-leaver and by 2006 this number had decreased to 12.9 percent (Ministry of Education 2006). This is lower than the average of 25 percent in all $25 \mathrm{EU}$ countries, but higher than e.g. the situation in Denmark. Agreed by the EU countries in the so-called Lisbon goals the proportion of early schoolleavers should decrease further in the period till 2010. For the Netherlands the policy goal is to decrease the proportion of early school-leavers to 8 percent in 2010.

Due to the increasing scientific interest in the causes and consequences of early school-leaving, literature on the subject is quite broad and the understanding on why some students leave school early has grown. Early school-leavers are less intelligent and perform worse on scholastic tests as compared to students that do not drop out of school (Audas and Willms 2001; Alexander, Entwisle and Kabbani 2001; Ensminger and Slusarcick 1992; Cairns, Cairns and Neckerman 1989). In addition, early school-leavers are less motivated to do well in school and tend to feel less happy in the school environment (Audas and Willms 2001; Alexander, Entwisle and Horsey 1997; Hofman 1993). In terms of risk-groups it has been shown that males and ethnic minorities have a higher risk on early school-leaving (Marks and Fleming 1999; De Wit and Dekkers 1997; Rumberger 1995). Furthermore family background turns out to be a powerful predictor of early school-leaving: students from parents who are low-educated or have low socio- 
economic status are more likely to leave school without a diploma (Alexander et al. 2001; Rumberger 1983).

Figure 1

The Dutch educational system

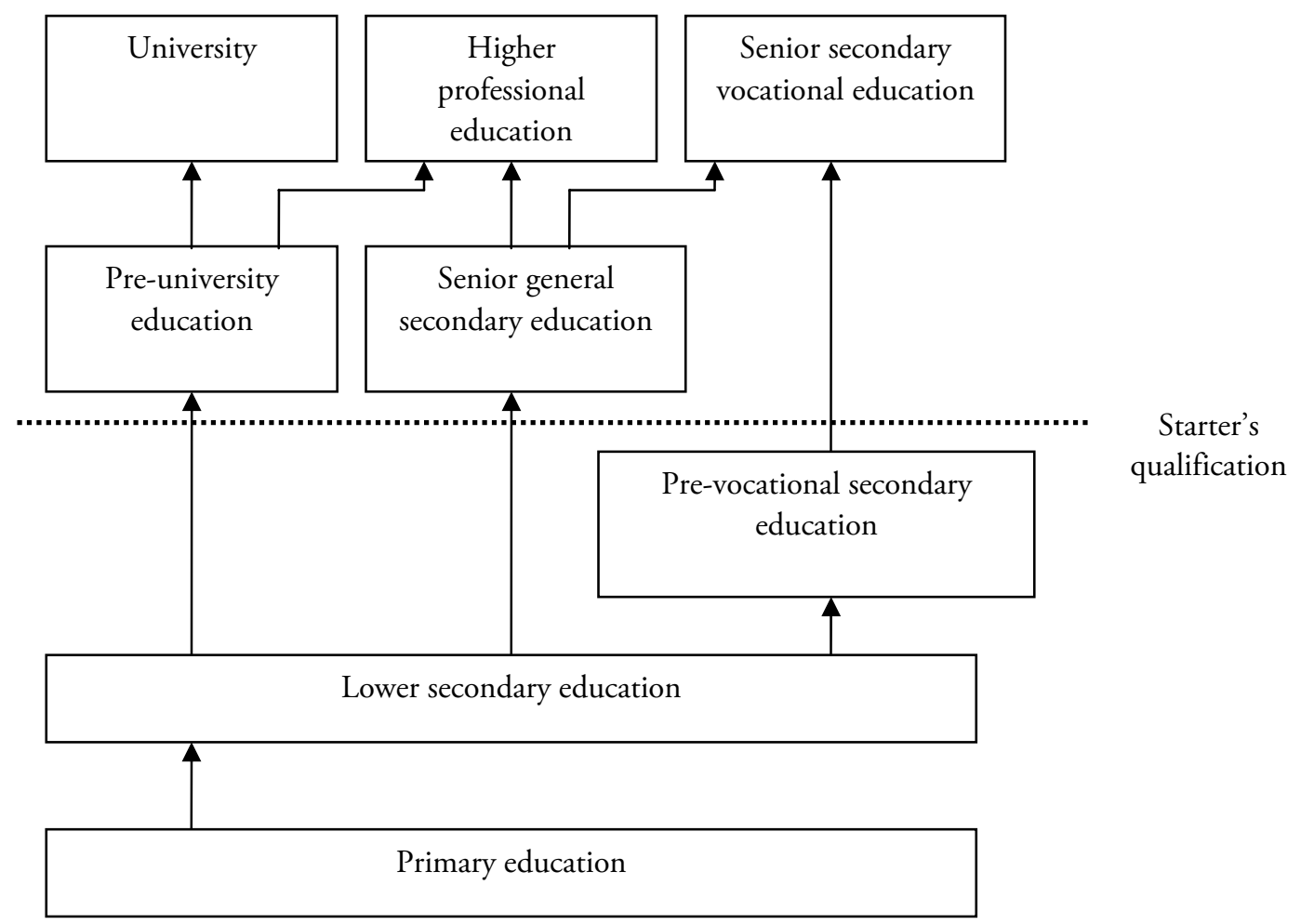

The Dutch secondary educational system differs from the system in the United States in that it is highly stratified (see figure 1 for an overview of the Dutch educational system). At the age of twelve, after primary education, students can choose between three tracks of education, each aiming at a different educational level. They can go to pre-vocational secondary education (VMBO) which lasts four years and prepares for upper secondary vocational education (MBO: ISCED 3C). The second track in Dutch secondary education is senior general secondary education (HAVO), which lasts five years and prepares for higher vocational education (HBO: professional bachelors). The third track is pre-university education (VWO), 
which lasts six years and prepares for studies at university level (academic bachelors and masters). Note that the US High School Diploma cannot directly be compared to one of these tracks since High School Diploma's entail much more variation between students in level and orientation of the programs followed than the Dutch educational tracks that are more standardized. However, when distinguishing the different groups in our analysis we will try to link them to their US counterparts.

This paper focuses on those students that are enrolled in the lowest track of secondary education, the pre-vocational secondary education (VMBO) which we will refer to as lower secondary education. This lowest track covers roughly 55 percent of all enrollments at the start of secondary education. There are two reasons to focus on this specific group. First, early school-leaving occurs much more often in this track. On average three quarters of the new early school-leavers that are registered each year come from lower secondary education (VMBO). At the same time, early school-leavers from upper secondary general education (HAVO and VWO) often pursue their education in institutes not subsidized by the Ministry of Education, but still leading to a recognized diploma. However this enrollment in non-subsidized education is not monitored in our sample so that early school-leaving from these groups would be severely overestimated. The second reason to focus on this specific group is the fact that they are the ones most at risk on the labor market. Due to the increasing educational requirements on the labor market and the resulting crowding-out of lower educated, a new underclass of low-educated youngsters is emerging. Especially the drop-outs from the lowest educational tracks experience the highest labor market integration problems (Traag et al. 2004; CPB 2006).

The scientific knowledge on the causes of early school-leaving is still very limited. "Although existing research on the causes of dropping out of school is extensive, it suffers from several shortcomings. First, few research studies have attempted to model dropout behavior in a comprehensive fashion, simultaneously accounting for he effects of individual, family, and school factors and distinguishing between truly independent 
factors, such as ethnicity and family background, and such intervening factors as school behavior and academic achievement. Second, previous predictive studies have tended to focus on descriptive and structural characteristics of students and their families - such as a student's ethnicity or family socioeconomic status - which reveal very little about the underlying processes that influence school achievement and dropout behavior" (Rumberger 1995, pp. 585). Although Rumberger came to this conclusion over a decade ago, his observation still holds true. In this paper we will advance the current knowledge on early school-leaving in three ways. First, we will use a more complete model, taking into account individual, family and school factors ${ }^{1}$ at the same time. Second, we will use longitudinal panel data which may permit us to attribute clear causal relations between the different factors since all variables used in our analysis were measured prior to the event of early school-leaving. Third, instead of comparing just two groups - dropouts and those who stay in education we will take a more differentiated view. In 1993 the Dutch Ministry of Education introduced the term "Starter's Qualification", defining the minimum level of education a person should acquire to be successful on the labor market. Those who leave school without a diploma of upper secondary vocational education (MBO) or upper secondary general education (HAVO or VWO) are considered to be early school-leavers and schools are legally obliged to register them so that proper actions can be taken to let them return to some form of education. Yet, although schoolleavers who did not obtain a full upper secondary qualification are formally considered early school-leavers, the variation in this group in terms of achieved educational level and opportunities on the labor market is still significant (Van der Velden et al. 2002; De Vries et al. 2003).

Therefore we divided our group of early school-leavers into three subgroups based on their achieved educational level. The first group is composed of those who left

1. Apart from individual and environmental factors, other factors such as the economic climate can also influence early school-leaving, pushing and or pulling young people from school into the labor market. However we will not discuss these factors in this paper. 
lower secondary education (VMBO) without a diploma. This group is usually referred to in the literature as 'dropouts', the most problematic group since they did not obtain any type of qualification and therefore will experience serious problems when making the transition to the labor market. In the US, this group would be equivalent to students leaving High School in grade 10 or before without a diploma. The second group did obtain a diploma in lower secondary education (VMBO) and either left full time education immediately after graduating or continued in full time education for some time but never attained a diploma. We will refer to this group as 'low educated'. In the US this group would be equivalent to school-leavers from grade 10 with a vocational certificate. Compared to the first group of school-leavers, they are probably more successful in entering the labor market. Yet, a diploma in lower secondary education is not regarded as a sufficient qualification to successfully enter the labor market. The third group is composed of those who successfully attained a diploma in lower secondary education and then continued education in an apprenticeship training ('leerlingwezen' in Dutch). In apprenticeship training students go to school part-time for theoretical training while the company that employs the apprentice provides practical training. ${ }^{2}$ Apprenticeship training is considered to be a starter's qualification and is therefore comparable to fulltime upper secondary vocational education (MBO). However, apprenticeship training aims at a different type of students, i.e. those who prefer to start working and combine this with vocational training. Therefore we kept them as a separate group in our analysis. This group is referred to as the 'apprentices' and is comparable to school-leavers from grade 10 with a vocational certificate who pursue their education in a 2-year apprenticeship program. We will compare the characteristics of these three groups of early school-leavers to the characteristics of those who continued education after attaining a diploma in lower secondary education and attained a higher level of secondary education. For most of them

2. Part-time training is not included in the regular VOCL-follow-up study so there is no information on the student's educational career once they have left full-time education. Therefore, it is unclear whether one successfully finished this type of training. 
this will be upper secondary vocational education ('MBO' in Dutch). They can be regarded as the ones most likely to succeed in the labor market compared to the ones without any qualification (the 'dropouts') and the ones that only completed lower secondary education (the 'low educated'). Note however that this group is still considered to be at the lower end of the educational specter, because the majority will not have obtained a higher education degree. In the US this group would be equivalent to people who have only a high school diploma (grade 12) or an associate degree in a vocational/technical institution or community college and who are not going to higher education.

\section{Theory and hypotheses}

Early school-leaving can be explained by several factors. We distinguish three groups of explanatory factors. ${ }^{3}$ The first group of explanatory factors concerns the characteristics of the students themselves, the individual characteristics. Individual characteristics are for instance gender and ethnicity, and traits like motivation and cognitive skills. The second group is related to the family of origin. Family characteristics that are important in explaining early school-leaving are cultural and social capital as well as the family composition. The third group concerns characteristics of the school, i.e. the share of ethnic minorities; the level of urbanization and the homogeneity of the school. Our first research question is: "Which individual, family and school characteristics influence the risk of early schoolleaving?" To answer this question we will formulate separate hypotheses in the section below.

As was explained in the introduction we will differentiate between four groups of school-leavers, comparing three groups of early school-leavers to students who did

3. Although the separation of some of the factors mentioned is quite artificial in some cases, we used this structure by means of clarity. 
attain a full upper secondary qualification. ${ }^{4}$ Our goal is to identify differences in risk factors of early school-leaving and to establish whether there are in fact different subpopulations within the total group of early school-leavers. Therefore our second research question in this paper will be: "Is there a difference between the subgroups of early school-leavers in the effects of individual, family and school characteristics?”

\section{Explaining early school-leaving from individual characteristics}

Demographic individual characteristics like gender and ethnicity play an important role in explaining early school-leaving. Males and ethnic minorities are more likely to leave school without a full upper secondary qualification. This leads to the first hypotheses on individual explanations of early school-leaving:

1) Students from ethnic minorities are more at risk of leaving school prematurely than native students.

2) Males are more at risk of leaving school prematurely than females.

A second important factor concerns the students' cognitive abilities. Early schoolleavers are less intelligent and perform less well in school compared to other students (Audas and Willms 2001; Alexander et al. 2001; Ensminger et al. 1992; Cairns et al. 1989). Still, differences in cognitive abilities are not the only thing that distinguishes dropouts from non-dropouts. When comparing graduates, dropouts and non-graduates, i.e. those students who remained in high school for four years but did not attain the high school diploma, Barrington and Hendricks found evidence that dropouts did not work to their full potential (Barrington and Hendricks 1989). Although dropouts also showed significantly lower levels of intelligence, their lack of capacities was not the only reason why they were more prone to drop out. Early school-leavers also show a lack of aspirations as well as

4. Yet, this effect of gender is not found in all studies (Barrington and Hendricks 1989). 
motivation (Audas and Willms 2001; Alexander et al. 1997; Hofman 1993). These effects of intelligence, performance and motivation lead to the next hypotheses:

3) Early school-leavers perform less well in school.

4) Early school-leavers are less intelligent.

5) Early school-leavers show lower levels of school motivation.

Recently, studies on differential selection between males and females have shown that low-ability males are selected out of university-bound programs early (Baucal et al. 2006). In the Netherlands males are disadvantaged in their educational careers in a number of ways. They have been shown to attend special education more often than females, they perform less well in school and the number of males entering higher education is significantly lower than that of females (Veemdrick et al. 2004). It is not quite clear whether this lower performance of males is due to lower cognitive abilities or whether the effects of cognitive abilities are stronger for males than for females. To test this last assumption, we added the following extension to our gender hypothesis:

6) The effects of cognitive abilities on early school-leaving are stronger for males than for females.

The fourth individual factor is participation and identification. The association between engagement and academic performance is explained in Finn's taxonomy of engagement or participatory behavior (Finn and Rock 1997). According to Finn's model, students do well in school by participating. Participation in school is divided into three levels. The first level is the most basic level of engagement, involving the student's compliance to school and class rules like coming to class on time. Those who do not comply with these rules are very likely to experience difficulties in school. The second level involves the initiative taken by the student. More enthusiasm and initiative and therefore more intense participation in school positively affect a student's scholastic performance and decrease the risk of leaving school early. The third and highest level is engagement in extracurricular activities, social events and sports. Being involved so deep in the school's activities decreases 
the risk of early school-leaving even further. Participating in school leads to identification (Beekhoven 2004; Voelkl 1995). When students identify with school, participation is strengthened and students like being in school. Lacking identification with school leads to a decrease in participation and a disliking of school and thus increases the risk of early school-leaving (Audas and Willms 2001; Alexander et al. 1997; Hofman 1993). Australian research by Marks (1998) showed that students that like school are less likely to leave school early, independent of school performance. Although the effects were quite small, this suggests that children to some extent base their choice to leave school on their (dis)like of school. This leads to the hypothesis that:

7) Students who do not identify with their school are more at risk of leaving school early than students that do identify with school.

\section{Family-related factors explaining early school-leaving}

Differences in school success do not only relate to differences in individual characteristics, but also to differences in background. According to Boudon's theory of social stratification (Boudon, 1974), educational choices depend on the social class one belongs to. For those that belong to lower social status groups, the costs of staying in school are relatively large. At the same time, the relative importance of education is smaller in low social classes compared to high social classes. Therefore the social returns of education are smaller for students from low status groups. Thus the high costs and the low social returns of education make early school-leaving more likely for students from low socio-economic status. For students from high social classes the costs of education are relatively lower but the returns of higher education are higher since high educational levels are more common in high status groups. It has been shown that students of high social class are more successful in education (Shavit and Blossfeld 1993; O’Brien 2003). Students from high social classes would therefore be less likely to leave school before graduating (Boudon 1974). Although the association between social background and educational attainment has decreased over time (De Graaf 1993), 
it remained relatively high for the low educated (Hout 1988) and thus still of great importance in explaining the problem of early school-leaving.

To understand how social origin leads to educational inequalities, we will distinguish between parents' educational level and occupational status, as well as between different kinds of financial and cultural resources (De Graaf and De Graaf 2002). These different resources determine the relative costs and benefits of staying in education. We distinguish the following four factors: economic capital, human capital, social capital and cultural capital.

The first dimension in background is the economic capital of the family. Having sufficient financial resources enables parents to provide their children with material goods they need in order to perform well at school like books and other teaching materials (De Graaf 1986; Coleman 1988). The income of the parents is highly dependent on whether or not they have paid work and if so what occupational group they belong to. Children of non-employed parents will have lower amounts of financial resources and therefore are more prone to leave school early than children of high-skilled professionals. Australian research showed that school dropouts were more often from families where the father had a manual rather than a professional occupation and where family income was low (Lamb 1994). This leads to the hypothesis:

8) Students from lower social classes are more at risk of leaving school early.

The second dimension is buman capital. The human capital of the family is measured by the educational level of the parents and constitutes the extent to which the student grows up in a cognitive stimulating environment. Higheducated parents are better able to help their child e.g. when doing homework. Families where the parents are higher educated are more likely to have greater knowledge of the school system and to view higher education as the preferred destiny for their children (Lamb 1994; Rumberger 1983). Thus:

9) Students from low educated parents are more at risk of leaving school early. 
Cultural capital is an important factor in explaining intergenerational transmission of inequality (Bourdieu and Passeron 1977; DiMaggio 1982). Children from parents with high levels of cultural capital are better able to adjust to the dominant culture in schools than children from parents with less cultural capital. Children from the cultural elite are more familiar with the culture in school and their behavior and their views are more closely linked to the dominant school culture. The decomposition of cultural resources in high culture versus popular culture shows that both cultural capital and reading competencies affect children's educational outcomes (De Graaf and De Graaf 2001). Children from the cultural elite are therefore more successful in school than children of culturally deprived parents, irrespective of their cognitive skills (De Graaf 2002). Therefore we hypothesize:

10) Students with lower levels of cultural capital are more at risk of leaving school early.

The fourth family factor that is important in explaining early school-leaving is the family's social capital. The social capital in the family concerns among others the relationship between parents and children. An effective transmission of resources from parent to child requires sufficient interaction within the family (Coleman 1988). If the social interaction between parents and children is problematic, the child will be less able to take over resources from its parents. When there is no interaction between parents and children, the children will not be able to benefit from their parents' resources. Children from single-parent families have less social interaction, because only one parent is available. This is also true for children in large families, where children need to share their interaction-time with other siblings. This means that children from either single-parent families and children from large families can take less advantage of their parents' resources, increasing the probability of leaving school early (McLanahan and Sandefur 1994; Ní Bhrolcháin, Chappell, Diamond and Jameson 2000; U.S. Department of Education 2001; Heard 2004). 
11) Students from single-parent families are more at risk of leaving school early.

12) Students with large numbers of siblings are more at risk of leaving school early.

\section{The influence of the school}

The third group of factors that has been shown to influence early school-leaving concerns characteristics of the school the student attends. Effects of school composition are of particular importance since they are the principal mechanism through which governments can combat the problem of early school-leaving (Audas and Willms 2001). Schools tend to differ greatly in terms of the number of early school-leavers and the educational performance of students. Over the last few years the attention on schools that are predominantly 'black's has risen and the Dutch government has tried to combat ethnic segregation but until now these attempts have been futile. At the same time the number of schools that are highly segregated has risen. This is mainly caused by the fact that in certain, mostly urban areas, the number of ethnic inhabitants grows while natives move out of the area. Local schools therefore become more and more populated by ethnic students. At the one hand there are a growing number of parents, especially the high educated parents that prefer predominantly white schools for their children because they believe black school culture to deviate too much from the home culture. At the same time ethnic parents tend to prefer white schools because they believe their children are better educated in white schools especially concerning education in the Dutch language (Karsten et al. 2002). Research on differences in school performance of students between black and white schools has shown that on average there are clear relationships between the school's racial mix and students' educational performances (Van der Werf, Lubbers and Kuyper 2002; Van Der Slik, Driessen and De Bot 2005). This leads to the hypothesis that:

5. In the Netherlands the largest numbers of ethic groups are Moroccans, Turks and people from the Dutch Antilles, Aruba and Surinam. 
13) Students in schools with a large share of ethnic students are more at risk of leaving school early.

Van der Werf, Lubbers and Kuyper (2002) showed that students in urban areas are less successful than students in non-urban areas. This leads to the following hypothesis:

14) Students in schools in urban areas are more at risk of leaving school early.

As outlined in the beginning, this study will focus on early school-leaving in the lowest track of secondary education (VMBO). Another form of school composition which is interesting in this respect is whether or not these schools offer the upper academic tracks as well. In the Netherlands, not all secondary schools provide each track. Some schools provide only one educational track, and are therefore referred to as homogeneous schools. But many schools provide all three tracks of secondary education, bringing together students from pre-university education (VWO), senior general secondary education (HAVO) and prevocational secondary education (VMBO). Bryk and Thum (1989) hypothesized that students in schools that are highly differentiated are more likely to be absent and in the worst case, will even leave school altogether. In their study, they focused mainly on the school's normative environment and the academic climate in the school, but also on compositional variables like the share of minority students and the academic differentiation. They found evidence that students in homogeneous schools are less likely to be absent or leave school permanently. One explanation could be that students in homogeneous schools are more alike at least on an academic level and therefore the social distance between students is rather small. In heterogeneous schools the student population is much more academically differentiated. In terms of the frog-pond-effect, students in lower secondary education will experience themselves to be the smallest frogs in the pond. Based on these results we will formulate the following hypotheses:

15) Students in heterogeneous schools are more at risk of leaving school early. 


\section{Data and method}

For this analysis we will use a large representative longitudinal survey carried out in the Netherlands by Statistics Netherlands and academic researchers (Centraal Bureau voor de Statistiek 1991; Driessen and Van Der Werf 1992). This survey, the so-called Secondary Education Student Cohort 1989 (VOCL'89) consists of 19,254 students from a random sample of 381 schools, who were in the first grade of secondary school in 1989/1990, and whose educational career was followed since then. Among other things, this means that an annual record has been kept in which year of the course and in what type of education the students were in each successive year. This makes it possible not only to determine the educational level at any time, but also to see if the students had to repeat classes or dropped out, or whether they transferred to a higher or lower track of education. Furthermore, tests of school performance and non-verbal intelligence were administered in the first of their secondary education. A written questionnaire was also given to the parents of the students at the start of the survey with the aim of collecting information about the families and the pupils.

Driessen and Van Der Werf (1992) tested the representativeness of the sample both on the school level and on the individual level of the students. On the school level analyses were carried out on the number of students in the first grade, the size of the municipality, region and denomination. Large schools (over 206 students in first grade) were underrepresented in the sample while schools with 56 to 65 students were slightly overrepresented. They also found that the largest municipalities were underrepresented as well as the Amsterdam region and the whole of the Northern-Holland province. This was caused by the relatively large proportion of Amsterdam schools that refused to participate in the study.

On the individual level analyses were carried out on the representativeness of the sample based on the educational tracks provided in the school, sex, school recommendation, availability of parental data from the parental questionnaire, availability of data on ethnicity, the number of students with special needs, the 
educational and occupational level of the parents and the participation in school performance tests. These analyses showed that the total number of students in prevocational secondary education $(\mathrm{VMBO})$ in the sample was consistent with the total population in the school year 1999/ 00. Students with missing data on ethnicity, parental occupation and parental education were shown to have lower scores on the school recommendation test and the scale for school perception, yet these differences were not significant. On the whole the survey can be regarded as nationally representative of all students who were in their first year of secondary education in 1989/1990. More specific information about the cohort-study in general and missing data analyses can be found in prior published VOCL reports (Statistics Netherlands 1991; Driessen and Van Der Werf 1992).

\section{Measuring early school-leaving}

There is no unambiguous way to measure early school-leaving. A number of very different definitions are used nationally as well as internationally. One way to define early school-leaving is to consider those who leave any type of education without qualification. In the literature, this is usually referred to as 'dropping out'. A second way to define early school-leaving is to consider all students who leave school before the end of compulsory education to be early school-leavers. A third definition for early school-leaving is by the level of education attained. In the Netherlands the Ministry of Education and Science introduced the concept of a 'starter's qualification' ('startkwalificatie' in Dutch). It is not a piece of paper, like a diploma, but it is merely a concept used by policymakers and researchers. The starter's qualification refers to the minimum level of education needed to find and keep a job (Ministerie van OC\&W 1993). Based on this idea, one could consider all students who did not attain a starter's qualification to be early school-leavers. These are only three ways to define early school-leaving that are used, but all three definitions show different numbers of early school-leavers, making it quite difficult to unravel the magnitude of the problem. At the same time, with very different educational systems in the European countries and differing durations of compulsory education, the comparability of figures is difficult. Measuring early 
school-leaving becomes even more difficult since educational careers are dynamic. A student can leave school in one year and return later in life. Is a student who left education at sixteen and returns at eighteen an early school-leaver or not?

As was explained in the introduction, we will focus only on students from lower secondary education (VMBO). Therefore all students that started their educational career in lower secondary education were selected from the VOCL'89. This is not a straightforward selection, since the majority of students in Dutch education do not start first grade in a specific track of education. Most first grades are heterogeneous, so that the student can choose the most suitable track at the end of first grade, depending on his or her academic results. In some schools, this principle of heterogeneous grouping can last even two years. Therefore, one cannot simply select students depending on the level of education in first grade. To determine whether a student was in lower secondary education (VMBO), we therefore used the first occurrence of a non-mixed educational level in the students' educational career as the selection criterion. From the initial population, all students that ever attended lower secondary education (VMBO) were selected, leaving out students who left school for compulsory military service and those who deceased or fell seriously ill during the survey. Thus even those students who started their educational career in one of the two higher tracks (i.e. senior general secondary education HAVO or pre-university education VWO), but returned later to the lower track were selected in our sample. This resulted in a total of approximately 10 thousand students in lower secondary education (VMBO) in VOCL'89. These students were then divided into four groups:

- those who left lower secondary education (VMBO) without a diploma $(\mathrm{N}=1,208)$;

- those who did obtain a diploma in lower secondary education (VMBO) and either left full time education immediately after graduating or continued in full time education for some time but never attained a diploma $(\mathrm{N}=3,409)$; 
- those who successfully attained a diploma in lower secondary education and then continued education in an apprenticeship training ('leerlingwezen' in Dutch) $(\mathrm{N}=1,034)$;

- those who continued education after attaining a diploma in lower secondary education and attained a higher level of secondary education $(\mathrm{N}=4,828)$

\section{Variables}

To measure demographic individual characteristics we used the student's gender and ethnicity. Ethnic background is measured by the country of birth of both the respondent and his or her parents. Someone is considered to belong to an ethnic minority if either the respondent or one of his or her parents were born in one of the non-western countries listed in the Employment of Minorities (Promotion) Act (Wet SAMEN).

The cognitive capacities of the student were determined on the basis of school performance, intelligence and school recommendation. The motivation of students concerns their achievement-motivation, i.e. the degree to which they are eager to do well in school. The participation and identification of the students are measured by the student's perception of school and their teachers.

Family resources are divided in four types of resources. Economic capital is measured by the occupational background of the parents. Human capital is measured by the level of education of the parents. Cultural capital is measured by the cultural participation and the reading behavior of the parents. Finally, social capital is measured by the amount of educational support at home, the family type (i.e. single-parent family versus two-parent family) and the number of children in the family.

The influence of the school is measured in four variables: the heterogeneity of the school (schools providing solely lower secondary education (VMBO) versus schools having higher levels of secondary education in the same school), the share of (non- 
western) ethnic minorities in the school and the degree of urbanization of the school's region. For all three variables the deviation of the mean for all schools is analyzed. See appendix 2 for more details on variables used in the analysis.

\section{Statistical modeling issues}

The statistical modeling involves the de-composition of the total effect of individual-, family- and school characteristics on early school-leaving into two sources of variation: differences on the individual level and differences between schools. To deal with this, we will use random coefficient or multilevel models. The basic idea of multilevel analysis is that data that have a nested structure, are not adequately represented by the probabilistic model of multiple regression analysis, but should be analyzed in a hierarchical linear model or random coefficient model (Snijders and Bosker 1999, Goldstein 1995). We will use a multinomial logistic model to take account of the fact that our dependent variable has four categories. Our model has a hierarchical structure in which individuals $i$ are nested in schools $j$. In this model $t$ denotes the reference category: students who gained a diploma in full upper secondary education. For each of the remaining $t-1$ categories $s$ the two-level random intercept model specified is:

$$
\log \left(\frac{\pi_{i j}^{(s)}}{\pi_{i j}^{(t)}}\right)=\beta_{0}^{(s)}+\beta_{1}^{(s)} X_{i j}+u_{j}^{(s)}
$$

where $U_{j}^{(s)}$ is a school-level random effect, assumed to be normally distributed with mean 0 and variance $\sigma_{u}^{2(s)}$.

\section{Results}

In our models we distinguish three groups of school-leavers, those that left school before graduating (group I: 'dropouts'), those who did achieve the diploma and subsequently left school (group II: 'low-educated') and those who left full-time education to pursue an education in apprenticeship training (group III: 
'apprentices'). Since the main aim of the paper is to analyze characteristics that influence early school-leaving we compare each of the three types of early schoolleavers to those who did attain a full upper secondary education qualification. However, the table also shows whether effects differ significantly between adjacent groups.

Table 1

Individual and school-level influences on early school-leaving from lower secondary education2: logit effects (odds ratios in brackets)

\begin{tabular}{|c|c|c|c|c|c|c|}
\hline \multirow{2}{*}{$\begin{array}{l}\text { Independent variables } \\
\text { Individual level }\end{array}$} & \multicolumn{2}{|c|}{ Group 1: 'Dropouts' } & \multicolumn{2}{|c|}{ Group ll: 'Low-educated' } & \multicolumn{2}{|c|}{ Group lll: 'Apprentices' } \\
\hline & & & & & & \\
\hline Intercept & $4,036^{* *}$ & & $6,198^{* *}$ & & 0,524 & \\
\hline \multicolumn{7}{|l|}{ Demographic individual characteristics } \\
\hline \multicolumn{7}{|l|}{$\operatorname{Sex}$} \\
\hline Male & $1,933^{* *}$ & $(6,910)$ & 0,348 & $(1,416)$ & $3,813^{* *}$ & $(45,286)$ \\
\hline \multicolumn{7}{|l|}{ Female (ref). } \\
\hline \multicolumn{7}{|l|}{ Ethnicity } \\
\hline \multicolumn{7}{|l|}{ Native (ref). } \\
\hline Foreign & 0,043 & $(1,044)$ & $-0,179^{*}$ & $(0,836)$ & 0,035 & $(1,036)$ \\
\hline \multicolumn{7}{|l|}{ Cognitive capacities } \\
\hline Intelligence & $-0,199$ & $(1,044)$ & $-0,022$ & $(0,836)$ & 0,184 & $(1,036)$ \\
\hline School performance & $-2,170$ & $(0,114)$ & $-1,215^{* *}$ & $(0,297)$ & $-1,765^{* *}$ & $(0,171)$ \\
\hline School recommendation & $-0,327^{* *}$ & $(0,721)$ & $-0,637^{* *}$ & $(0,529)$ & $-0,073$ & $(0,930)$ \\
\hline \multicolumn{7}{|l|}{ Participation and identification } \\
\hline School motivation & $-1,125^{* *}$ & $(0,325)$ & $-0,458^{* *}$ & $(0,633)$ & $-0,467^{*}$ & $(0,627)$ \\
\hline School perception & $-0,429^{*}$ & $(0,651)$ & $-0,464^{* *}$ & $(0,629)$ & $-0,352$ & $(0,703)$ \\
\hline \multicolumn{7}{|l|}{ Economic capital } \\
\hline \multicolumn{7}{|l|}{ Social class } \\
\hline Manual laborers & $-0,709^{* *}$ & $(0,492)$ & $-0,208^{* *}$ & $(0,812)$ & $-0,285^{* *}$ & $(0,752)$ \\
\hline Self-employed, no employees & $-1,105^{* *}$ & $(0,331)$ & $-0,642^{* *}$ & $(0,526)$ & $-0,757^{* *}$ & $(0,469)$ \\
\hline Self-employed, with employees & $-0,807^{* *}$ & $(0,446)$ & $-0,355^{* *}$ & $(0,701)$ & $-0,778^{* *}$ & $(0,459)$ \\
\hline Skilled blue-collar workers & $-0,704^{* *}$ & $(0,495)$ & $-0,276^{* *}$ & $(0,759)$ & $-0,232$ & $(0,793)$ \\
\hline Office workers & $-0,775^{* *}$ & $(0,495)$ & $-0,401^{* *}$ & $(0,759)$ & $-0,423^{* *}$ & $(0,793)$ \\
\hline Professionals & $-0,738^{* *}$ & $(0,478)$ & $-0,643^{* *}$ & $(0,526)$ & $-0,326^{*}$ & $(0,722)$ \\
\hline \multicolumn{7}{|l|}{ Unemployed (ref). } \\
\hline \multicolumn{7}{|l|}{ Human capital } \\
\hline Parental education & $-0,071^{* *}$ & $(0,931)$ & $-0,060^{* *}$ & $(0,941)$ & $-0,036^{* *}$ & $(0,964)$ \\
\hline \multicolumn{7}{|l|}{ Cultural capital } \\
\hline Cultural participation & $-0,398^{* *}$ & $(0,672)$ & $-0,337^{* *}$ & $(0,714)$ & 0,064 & $(1,066)$ \\
\hline Reading books & 0,135 & $(1,145)$ & $-0,036$ & $(0,964)$ & 0,053 & $(1,054)$ \\
\hline \multicolumn{7}{|l|}{ Social capital } \\
\hline Parental support & $-0,659^{* *}$ & $(0,517)$ & $-0,448^{* *}$ & $(0,639)$ & $-0,374^{* *}$ & $(0,688)$ \\
\hline Family type & & & & & & \\
\hline
\end{tabular}


Table 1 (continued)

Individual and school-level influences on early school-leaving from lower secondary education2: logit effects (odds ratios in brackets)

\begin{tabular}{|c|c|c|c|c|c|c|}
\hline Single parent & $0,268^{* *}$ & $(1,307)$ & $0,213^{*}$ & $(1,237)$ & $-0,339^{*}$ & $(0,712)$ \\
\hline \multicolumn{7}{|l|}{ Two parents (ref). } \\
\hline \multicolumn{7}{|l|}{ Number of children in the family } \\
\hline One child & $0,321^{* *}$ & $(1,379)$ & 0,135 & $(1,145)$ & $-0,160$ & $(0,852)$ \\
\hline \multicolumn{7}{|l|}{ Two or three children (ref.) } \\
\hline Four children or more & $0,620^{* *}$ & $(1,859)$ & $0,377^{* *}$ & $(1,458)$ & 0,123 & $(1,131)$ \\
\hline \multicolumn{7}{|l|}{ School level } \\
\hline$\%$ of foreign students & $0,013^{*}$ & $(1,013)$ & 0,008 & $(1,008)$ & 0,003 & $(1,003)$ \\
\hline \multicolumn{7}{|l|}{ Municipality } \\
\hline Very high & 0,165 & $(1,179)$ & $-0,196$ & $(0,822)$ & $-0,051$ & $(0,950)$ \\
\hline High & $0,376^{*}$ & $(1,456)$ & 0,147 & $(1,158)$ & 0,289 & $(1,335)$ \\
\hline Moderately high (ref.) & - & & - & & - & \\
\hline Low & $-0,349^{*}$ & $(0,705)$ & $-0,335^{* *}$ & $(0,715)$ & $-0,093$ & $(0,911)$ \\
\hline Very low & $-0,343$ & $(0,710)$ & $-0,288$ & $(0,750)$ & $-0,245$ & $(0,783)$ \\
\hline \multicolumn{7}{|l|}{ School heterogeneity } \\
\hline \multicolumn{7}{|l|}{$\begin{array}{l}\text { Includes no higher education } \\
\text { than VMBO (ref) }\end{array}$} \\
\hline Includes higher levels of education & $-0,305^{*}$ & $(0,737)$ & $-0,233^{*}$ & $(0,792)$ & $-0,121$ & $(0,886)$ \\
\hline Individual level interactions & $-0,197$ & $(0,821)$ & 0,135 & $(1,145)$ & $-0,459$ & $(0,632)$ \\
\hline Male ${ }^{*}$ intelligence & $-1,002^{* *}$ & $(0,367)$ & $-1,055^{* *}$ & $(0,348)$ & $-0,227$ & $(0,797)$ \\
\hline Male * school performance & $-0,084$ & $(0,919)$ & 0,112 & $(1,119)$ & $-0,397^{* *}$ & $(0,672)$ \\
\hline Male * school recommendation & $-0,740^{* *}$ & $(0,477)$ & $-0,444^{* *}$ & $(0,641)$ & $-0,426$ & $(0,653)$ \\
\hline Male * school motivation & 0,216 & $(1,241)$ & 0,176 & $(1,192)$ & 0,473 & $(1,605)$ \\
\hline Male * school perception & $4,036^{* *}$ & & $6,198^{* *}$ & & 0,524 & \\
\hline
\end{tabular}

${ }^{* *}=\mathrm{p}<0.01 ;{ }^{*}=\mathrm{p}<0.05$ with reference category $=$ Left full-time education with a full upper secondary qualification bold $=\mathrm{p}<0.01 ;$ italic $=\mathrm{p}<0.05$ with reference category $=$ adjacent group

ref. $=$ reference category

\section{Dropouts}

Students who leave education without attaining any type of diploma are the most problematic. They are usually referred to as 'dropouts'. Males are about seven times more at risk of dropping out before attaining the diploma than females. When controlling for individual-, family- and school-characteristics, students from ethnic minorities are not significantly more at risk of dropping out then those who do attain a full upper secondary qualification yet they are significantly more likely to leave school after attaining a diploma in lower secondary education ('low- 
educated'). ${ }^{6}$ When considering cognitive capacities of dropouts, students who leave school without any diploma perform less well in school and received a significantly lower school recommendation at the end of primary education than students who did attain a diploma in upper secondary education or higher as well as compared to the adjacent group. At the same time, these students are less motivated ${ }^{7}$ and they do not perceive school to be a very positive environment. Note again that all variables were measured at age twelve, so well before the actual dropout took place. Although these factors are probably interrelated, they still have their own direct effects on dropping out of school. Note that given the interaction term with sex, the estimates in the table present the effects for females. The interaction effects of sex by cognitive capacities also show significant differences between males and females. Males are more strongly affected by their school performance and their school motivation in their chance of dropping out than females. These effects are not significantly different from the adjacent group of 'low-educated'.

In general, students from low social classes (i.e. the reference group, non-employed parents) are about fifty percent more at risk of dropping out of school than all other social groups. For students with self-employed parents the risk of dropping out seems to be the smallest. This could be caused by the fact that these students want to take over their parents' business in the future, giving them a clear goal in

6. Although similar results were found in a number of studies, some caution on this finding is warranted. The effect of ethnicity is negative once we exclude parental educational level from the model. This could indicate some measurement error. It is possible that, when the parental educational levels were coded, diplomas attained outside the Dutch educational system were systematically rated too low. If the educational level of parents from ethnic minorities is systematically underestimated, this would show up as a negative effect for ethnic minorities on the chance of early school-leaving.

7. Since motivation is arguably endogenous to the schooling process, because the same family and school factors that lead to high motivation can also lead to dropping out, we estimated our model without motivation first. However this did not change the results. Since student motivation was measured well before students made the decision to leave school, we decided to keep this variable in the model. 
life. Effects for social class are significantly stronger when considering the risk of leaving school without any diploma ('dropouts') compared to those that leave school after attaining a diploma in lower secondary education ('low-educated'). Parental education also shows a significant relationship to the risk of dropping out. For every additional year of parental education, the risk of dropping out of school decreases by 7 percent. Cultural participation is negatively linked to the relative risk of dropping out of school. Having parents who frequently visit museums, concerts and theatre decreases the dropout risk. Parental reading behavior however showed no significant effect on dropping out. The amount of social capital available is important in explaining dropout behavior. Having highly supportive parents can decrease the risk of dropping out by more than 50 percent compared to having totally unsupportive parents. At the same time the family composition and the number of children in a family are also of importance. Children from singleparent families and children in families with four or more children are more at risk of dropping out. However, growing up as an only child also increases the risk of dropping out significantly. This is contradictory to the assumption that having fewer children increases the transmission of social capital, therefore decreasing the risk of early school-leaving. Maybe parents with only one child have more opportunities to stay working full-time, therefore effectively decreasing the available time per child, compared to the two-child families. Unfortunately, our data do not allow us to test this hypothesis.

School-level factors partly explain dropout risks. One factor is the share of students from ethnic minorities in the school. Having relatively large numbers of students from ethnic minorities in the school increases the risk of dropping out. Note that this effect is controlled for the individual effect of being a minority student. The risk of dropping out is higher in an entirely 'black' school compared to an entirely 'white' school. In general, decreasing the share of students from ethnic minorities in a school by 10 percent leads to a 13 percent decrease in dropout risk. The urbanization rate of the school-region is only partly related to dropout. Students in highly urbanized regions are about 1,5 times more at risk of dropping out than 
students in moderately urbanized regions. Dropout risks in very low urbanized regions or very highly urbanized regions however are not significantly different from dropout risks in moderately urbanized regions, but this may very well be caused by a relative low number of observations of schools in very high urbanized regions. The risk effect of being in a school in a highly urbanized region is significantly larger for dropping out without any qualifications compared to leaving school after attaining a diploma in lower secondary education. The third schoollevel factor in the model is the schools' heterogeneity, i.e. if the school provides only lower secondary education or includes higher levels of secondary education as well. We expected students in heterogeneous schools to perform less well and therefore to be more at risk of dropping out because it is harder for students at the lowest levels of education in these schools to meet the academic expectations. However, the analysis shows the opposite to be true. Students from lower secondary education are less at risk of dropping out of school when being in a school that provides higher tracks of secondary education as well. So maybe instead of being deterred by being in a more academic environment, students in lower levels of education appear to be encouraged to stay in school, maybe as a result from the more academic climate. At least the risk of dropping out is reduced by 25 percent.

\section{Leaving school after lower secondary education}

In general, the group that leaves fulltime education after attaining the diploma in lower secondary education (the 'low-educated') is similar to the dropout group in terms of characteristics that explain early school-leaving but the effect sizes are generally smaller. There are some differences however. First, there is no significant difference between males and females when considering the risk of leaving school after completing lower secondary education. However, when comparing the sex effect for this group to the risk of entering an apprenticeship program, males are significantly more likely to leave fulltime education for apprenticeship training since the sex effect for the latter group is significantly larger. Our ability-by-sex interactions show comparable results as were shown previously. Again, males are 
more strongly affected by their school performance and school motivation in the risk of leaving school compared to females.

Second, students from ethnic minorities are about 18 percent less at risk of leaving school after graduating from lower secondary education. This is a quite surprising finding since most studies find students from ethnic minorities to be more at risk of early school-leaving (Marks \& Fleming 1999; De Wit \& Dekkers 1997; Rumberger 1995). However they usually do not take into account the other characteristics of the students, the family and the school simultaneously like we do in this model.

The third difference in characteristics explaining early school-leaving is the lack of an effect of being an only child. In terms of dropout risk we showed that children without siblings had a higher risk of dropping out of education, contradicting the theory of the dissemination of social capital. When assessing the risk of leaving school after a diploma in lower secondary education however being an only child does not significantly increase the risk of early school-leaving.

The fourth difference between both groups is the fact that, in contrast to dropout risks, students are not more at risk of leaving school after lower secondary education when being in a predominantly black school. The share of students from ethnic minorities in a school shows no significant effect in the risk of leaving school early for this group of school-leavers. Finally, we show that being in a low urbanized region significantly decreases the risk of leaving school after finishing lower secondary education. Yet risks are no higher in highly urbanized areas compared to the risk in moderately urbanized areas. 


\section{Leaving fulltime education and participating in an apprenticeship program}

Students who continue education in an apprenticeship program after lower secondary education are not considered early school-leavers since they will obtain the starter's qualification if they successfully finish the program. ${ }^{8}$ However, we expect students who decide to continue education part-time to be different from the ones that continue full-time education in terms of characteristics of students as well as their future perspectives. The results show clear differences between these two groups as well as compared to those who left school either totally unqualified or with only a diploma in lower secondary education. Males are more likely to be in an apprenticeship program than females. This is at least partly due to the fact that these programs are aimed at more male-dominated fields of training like construction and mechanics. Contrary to our previous findings, no significant differences were shown between males and females in the effects of school performance and motivation. However, males show stronger effects of school recommendation compared to females.

Again, there are no significant differences between native students and students from ethnic minorities, nor are there significant effects of intelligence. Students who choose part-time education performed less well in lower secondary education. Students choosing the apprenticeship track are significantly less motivated, but at the same time there are no significant differences in school perception compared to the reference group who stay in full-time education.

Students from low social classes are more likely to continue in part-time education, as well as students from low educated parents. Cultural capital, neither in the form of highbrow activities nor in terms of reading behavior shows no significant effects.

8. In the design of the VOCL-study, for all students who left fulltime education data collection stopped. Therefore it is unclear whether students who entered an apprenticeship program did successfully finish their program. 
Having supportive parents does significantly decrease the risk of continuing education part-time instead of full-time. Remarkably however, growing up with a single parent decreases the risk of entering part-time education instead of continuing full-time education. Other factors concerning the amount of social capital available showed no significant effects in our analysis.

Contrary to differences between students in the two first groups of early schoolleavers, we found no significant school effects for the likelihood of entering an apprenticeship program. Students from all high schools, black or white, urban or rural, homogeneous or heterogeneous are all equally likely to enter an apprenticeship program.

\section{Conclusion and discussion}

In this paper we used an elaborate multilevel model, consisting of individual and family-based characteristics on the first level and school-level factors on the second level, to explain early school-leaving.

Table 2 shows that most of our hypotheses on factors explaining early schoolleaving were confirmed in this study, supporting findings in previous studies on early school-leaving. Yet, this study has also advanced the knowledge on who leaves school early and why in at least two important ways.

First, we used an integrated model composed of individual characteristics like cognitive abilities, family resources like economic, human, cultural and social capital and school-level variables. By using such an elaborate model we were able to better identify what characteristics explain early school-leaving. An important finding concerned the stronger effects of cognitive abilities and school motivation on early school-leaving for males compared to females. These findings are in line with previous results found in Serbia (Baucal et al. 2006). The results also underline the importance of family resources, especially in terms of cultural and 
social capital. A surprising result compared to previous research is the fact that this study found no significant effects for the risk of dropping out of school for students from ethnic minorities when controlling for parental resources like social class and parental education. In fact, when considering the risk of leaving school after graduating from lower secondary education, ethnic minority students are less likely to leave school altogether.

\section{Table 2}

Overview of results

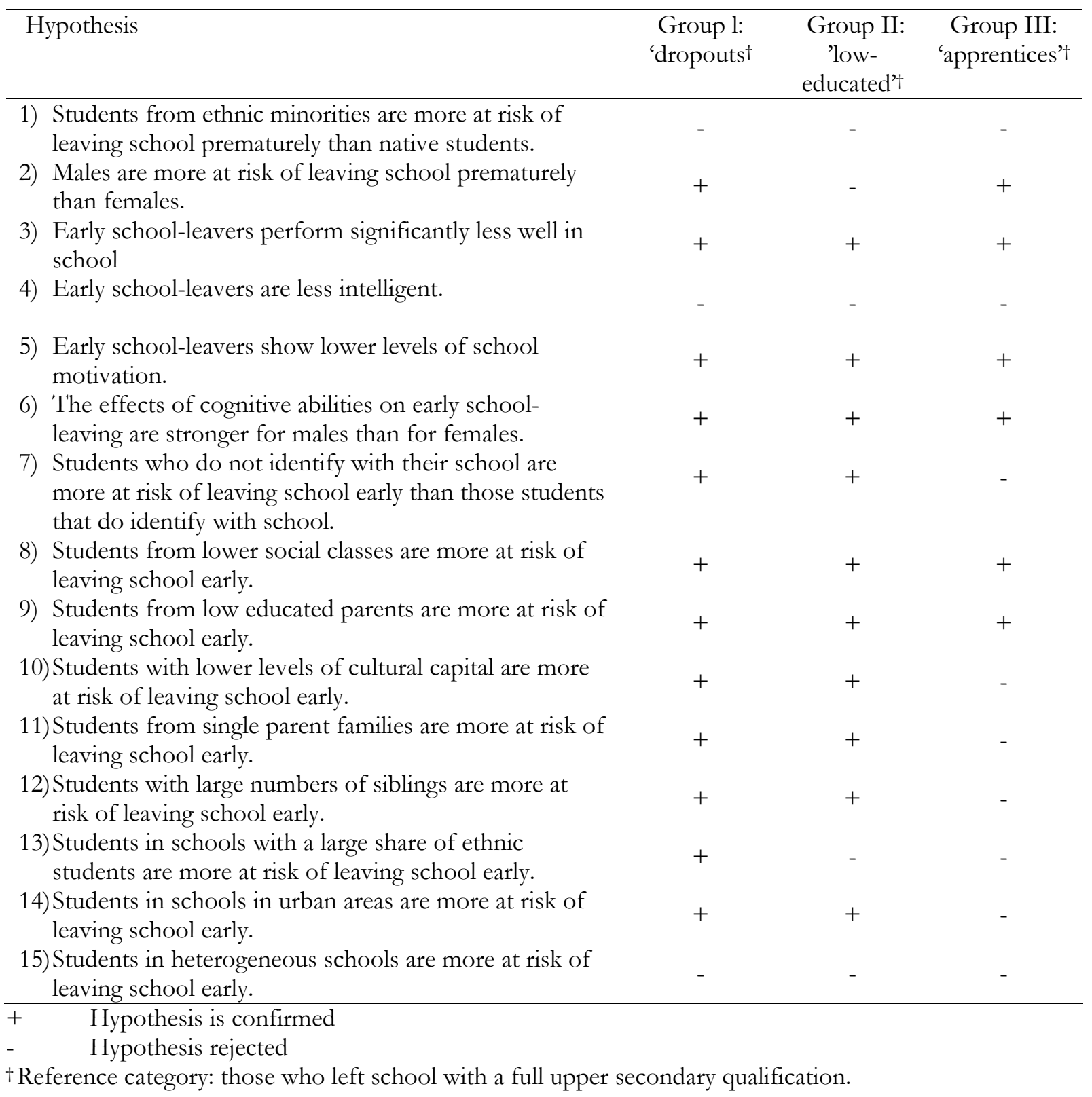


One explanation could be that these students are more motivated than native students. Goldsmith (2004) showed that black and Latino students have high occupational expectations, educational aspirations, and concrete attitudes compared to white students, which may serve as a protective factor against early school-leaving. Another study by Johnson, Crosnou and Elder (2001) showed that African American adolescents are more actively engaged in classroom and school activities. Thus these students may compensate the fact that they relatively more often stem from lower social backgrounds by higher levels of motivation and school perception.

A second advancement on previous studies is the differentiation of different groups of early school-leavers. Most studies limit the conceptualization of early schoolleavers to two groups, based on whether a person attained a diploma or not. In this study we distinguished four groups of school-leavers, separating 'real' dropouts and early school-leavers who left school after attaining a diploma in lower secondary education from those who continued education either part-time of full-time. Discerning these groups showed that dropout can be regarded as the lowest end of a scale of school success ranging from dropout, via leaving education after attaining a diploma in lower secondary education, going to an apprenticeship track to getting a full upper secondary qualification. The results show that the effects of all characteristics are always stronger for the dropout group than for the other two groups, suggesting that the underlying dimension is a continuum rather than a distinction between two or three totally different groups.

Finally, we used longitudinal data on a cohort of first grade students with a multitude of measurements on individual, family and school characteristics that were measured when students were still in first grade. This makes the direction of causality in our findings more plausible. Since education is compulsory until the age of sixteen, we can assume that the data relating to the explanatory factors were measured at least three years before the event of early school-leaving. This makes our findings especially valuable since this means that we are able to take an early 
start at combating early school-leaving focusing on students that lack motivation and positive school perception, students with poor cognitive abilities and students that stem from underprivileged families.

So why do students leave school before graduating in upper secondary education and what can we do to prevent some from early school-leaving? Preventive measures can be taken on the level of the student and his or her surroundings as well as at the level of schools. We also found evidence suggesting possibilities to combat early school-leaving on a more structural level.

\section{What can parents do?}

Parents play an important role in explaining early school-leaving. Results show that being involved in your child's educational career and being culturally active does indeed positively affect the chance of the child staying in school. Especially in families with large numbers of siblings and single-parents households, where parental involvement can be scarce, it is important to actively support the child's school career.

\section{School reforms}

Apart from individual characteristics, the risk of early school-leaving differs between schools. Our analyses showed that early school-leavers often are students who do have the cognitive abilities to follow education, but simply lack motivation or dislike school to the point that they can no longer identify with the school environment and drop out. Smerdon (2002) showed that there is a relationship between school performance and the sense of belonging. Students with poor school performance perceive lower levels of school membership. In turn, students who do not feel in place at school and perform poorly will probably loose the motivation to get their performance back on track. One way to decrease levels of early schoolleaving would be to focus more on ways to prevent poor performing students from feeling out of place in their school. 
Contrary to previous findings, being in a heterogeneous school does not increase the risk of early school-leaving. In fact, students in the lower tracks of schools that offer higher as well as lower tracks of secondary education are significantly less likely to leave school, than similar students in schools that offer only the lowest tracks. One explanation could be that these students in heterogeneous school more frequently interact with students from higher educational levels, thus improving their aspirations and performance (Bryk and Thum 1989). In schools with only the lowest tracks of secondary education, the academic climate is probably very poor, developing a culture where it is more appropriate to underachieve than to do one's best. On the other hand, in schools that also provide higher tracks of secondary education achievement may very well be a much more important part of school culture, even adopted by the students from the lowest educational tracks.

\section{Structural measures}

By separating real school-leavers from those who continued education in a parttime apprenticeship program, some differences emerged between these groups. Like the 'dropouts' and the 'low-educated' students left education after attaining a diploma, the students who enter an apprenticeship program performed less well in school and also lack motivation. But contrary to those who left school altogether, they did enter a part-time apprenticeship program, which could eventually lead to a recognized higher qualification. Maybe these are students who prefer more practical forms of education and less theory and in a sense 'regular' full-time education simply does not fit them. In our sample, about ten percent of all students choose to continue education in an apprenticeship program. In educational systems where there is no separate educational track that provides more practical education, like for instance the US, these students might be more inclined to leave school after graduating from lower secondary education or even would have dropped out. This can seriously increase the number of school-leavers that lack the skills needed to successfully enter the labor market. 


\section{Appendix 1 Measuring background variables, resources and control variables}

Ethnic background is measured by the country of birth of both the respondent and one of his or her parents. Someone is considered to belong to an ethnic minority if either the respondent or his or her parents were born in one of the non-western countries listed in the Employment of Minorities (Promotion) Act (Wet SAMEN).

The school recommendation is based on the recommendation that students were given by the primary school concerning the type of secondary education for which they were best suited. In the final year of primary education most children conduct a test (CITO-toets) which is comparable to the SAT. Based on this test and his/her own observations the primary school teacher will then give an advice for the type of secondary education most suitable for the student. This advice was coded on a scale developed by Bosker, Hofman and Van der Velden (1985) expressing the progress towards the top of the educational system.

School performance was based on the total score in three tests (Dutch, mathematics and the ability to process information), which were taken halfway during first grade. Each of the tests consisted of 20 multiple-choice questions. The values of Cronbach's alpha for the three tests were $0.76,0.84$ and 0.77 , respectively. The total score was expressed on a scale from 0 to 1 .

Non-verbal intelligence was measured using two tests. The first sub-test (PSB-3) measured the ability to reason and the second sub-test (PSB-8) the ability to abstract. Both sub-tests contained 40 items. The values of Cronbach's alpha were 0.82 and 0.90 , respectively. The numbers of correct items from both sub-tests were added together and this total sum was transformed to a scale with a minimum value of 0 and a maximum value of 1 . 
School motivation was measured using the following two statements presented to the students: 'I like to do my homework well, even if I find it difficult' and 'I don't try to do my best at school' (reversed). The average of both items was taken. The value of Cronbach's alpha was 0.45 . The total score was transformed to a scale from 0 to 1 .

School perception was based on a scale with 11 items on how students perceived the school ("I like going to school") their teachers ("My teachers are always fair") etcetera. It measures the degree to which a student likes school, and is used as a proxy for identification with school. The value of Cronbach's alpha for this scale was 0.75 . The scores on this scale range from 0 to 1 .

Two indicators determined the social background of the school-leavers, the educational level of the parents and the social class of the parents. The educational level of the parents was determined according to the Standard Education Classification 1978 (Centraal Bureau voor de Statistiek, 1987). The average educational level of both parents was used. The different levels were then converted to the average number of years of education according to the above-mentioned scale by Bosker, Hofman and Van der Velden (1985). The following values were assigned: 6 years (primary education, ISCED 0-1), 10 years (secondary education, lower level, ISCED 2), 14 years (secondary education, higher level, ISCED 3), 17 years (tertiary education, first phase, ISCED 5 bachelor) and 19 years (tertiary education, second phase, ISCED 5 master or ISCED 6). The social class of the parents was based on information about the type of work and the occupation of the main breadwinner in the family. The following categories were distinguished: 1) not employed, 2) manual laborers, 3) self-employed without employees, 4) selfemployed with employees, 5) skilled blue-collar workers, 6) office workers, and 7) professionals.

The cultural resources of the parents were measured according to their degree of cultural participation and their reading behavior. The items used in determining 
the position on the scale for cultural participation concerned the extent to which the parents visited museums, concerts and the theatre. The value of Cronbach's alpha for this scale was 0.88 . The items used in determining the position on the scale for reading behavior concerned the number of books read by the parents per month. The value of Cronbach's alpha for this scale was 0.40 . The scores on both scales were converted to values between 0 and 1 . The amount of parental educational support was based on questions to both parents about having discussions about school, having discussions about school performance and giving compliments about school performance. These items were combined to provide a scale with a minimum value of 0 and a maximum value of 1 . The value of Cronbach's alpha was 0.81 .

The type of family was derived from the questionnaire sent out to parents during the first secondary school year. If parents indicated that there was no second parent or caretaker present in the family, the family is considered to be single parent. In the same questionnaire parents were asked how many children were in the family, including the child in the sample.

The school's heterogeneity is divided into two groups: schools where there are only students on the lower secondary education level (i.e. VMBO) and schools that also consist of students from higher levels of secondary education (HAVO and VWO).

The percentage of students from ethnic minorities is computed by dividing the total number of ethnic minorities in the sample in the school by the total number of students in that school. Thus this figure is based on a total of 19,524 students in the initial sample. Then the deviation of the population mean was computed and used in the analysis.

The degree of urbanization is based on the number of addresses per $\mathrm{km} 2$ in the region. If there are 2,500 addresses or more, the urbanization rate is very high. Regions with 1,500 to 2,500 addresses are considered highly urbanized, while 
regions with 1,000 to 1,500 are considered moderately urbanized. Regions with 500 to 1,000 addresses have a low urbanization rate. Regions with less than 500 addresses are very low urbanized. 
Table 3

Univariate statistics for independent variables

\begin{tabular}{|c|c|c|c|c|c|}
\hline Variables & Mean & SD & $\%$ & Low & High \\
\hline \multicolumn{6}{|l|}{ Demographic individual characteristics } \\
\hline \multicolumn{6}{|l|}{ Sex } \\
\hline Male & & & 52.0 & & \\
\hline Female (ref). & & & 48.0 & & \\
\hline \multicolumn{6}{|l|}{ Ethnicity } \\
\hline Native (ref). & & & 88.3 & & \\
\hline Foreign & & & 11.7 & & \\
\hline \multicolumn{6}{|l|}{ Cognitive capacities } \\
\hline Intelligence & 0.47 & 0.23 & & 0 & 1 \\
\hline School performance & 0.41 & 0.24 & & 0 & 1 \\
\hline School recommendation & 6.6 & 0.76 & & 5 & 9 \\
\hline \multicolumn{6}{|l|}{ Participation and identification } \\
\hline School motivation & 0.49 & 0.29 & & & \\
\hline School perception & 0.49 & 0.29 & & & \\
\hline \multicolumn{6}{|l|}{ Economic capital } \\
\hline \multicolumn{6}{|l|}{ Social class } \\
\hline Manual laborers & & & 33.0 & & \\
\hline Self-employed, no employees & & & 4.7 & & \\
\hline Self-employed, with employees & & & 4.0 & & \\
\hline Skilled blue-collar workers & & & 9.4 & & \\
\hline Office workers & & & 18.3 & & \\
\hline Professionals & & & 11.0 & & \\
\hline Unemployed (ref). & & & 19.6 & & \\
\hline \multicolumn{6}{|l|}{ Human capital } \\
\hline Parental education & 10.3 & 3.1 & & & \\
\hline \multicolumn{6}{|l|}{ Cultural capital } \\
\hline Cultural participation & 0.47 & 0.28 & & & \\
\hline Reading books & 048 & 0.28 & & & \\
\hline \multicolumn{6}{|l|}{ Social capital } \\
\hline Parental support & 0.50 & 0.26 & & & \\
\hline \multicolumn{6}{|l|}{ Family type } \\
\hline Single parent & & & 7.5 & & \\
\hline Two parents (ref). & & & 92.5 & & \\
\hline \multicolumn{6}{|l|}{ Number of children in the family } \\
\hline One child & & & 7.3 & & \\
\hline Two or three children (ref.) & & & 78.4 & & \\
\hline Four children & & & 14.3 & & \\
\hline \multicolumn{6}{|l|}{ School level } \\
\hline $\begin{array}{l}\% \text { of foreign students above or below the } \\
\text { average in the sample }(\mu=12.2)\end{array}$ & 0 & 11.8 & & & \\
\hline \multicolumn{6}{|l|}{ Municipality } \\
\hline Very high & & & 12.5 & & \\
\hline High & & & 22.4 & & \\
\hline Moderately high (ref.) & & & 26.3 & & \\
\hline Low & & & 25.1 & & \\
\hline Very low & & & 13.7 & & \\
\hline \multicolumn{6}{|l|}{ School heterogeneity } \\
\hline Includes no higher education than VMBO (ref.) & & & 36.4 & & \\
\hline Includes higher levels of education & & & 63.6 & & \\
\hline
\end{tabular}

Note: Description based on 10,479 students in 361 schools 


\section{References}

Alexander, Karl, Entwisle, Doris and Carrie S. Horsey. 1997. From first grade forward: early foundations of high school dropout. Sociology of Education 70: 87-107.

Alexander, Karl, Entwisle, Doris and Nader Kabbani. 2001. The dropout process in life course perspective: early risk factors at home and school. Teachers College Record 103: 760-822.

Audas, Richard and J.Douglas Willms. 2001. Engagement and dropping out of school: A life course perspective. Working Paper for the Applied Research Branch, Strategic Policy, Human Resources Development.

Baucal, Aleksandar, Pavlovic-Babic, Dragica and J. Douglas Willms. 2006. Differential selection into secondary schools in Serbia. Prospects 36 (4): 539-546.

Barrington, Byron L. and Brian Hendricks. 1989. Differentiating characteristics of high school graduates, dropouts and nongraduates. Journal of Educational Research 82(6): 309-319.

Beekhoven, S. 2004. De rol van participatie en identificatie bij het voortijdig schoolverlaten van jongens. Pedagogische Studiën 81: 104-116.

Bosker, Roel J., Hofman, W.H. Adriaan and Rolf K.W. Van der Velden. 1985. Een generatie geselecteerd. Deel I: De loopbanen. Groningen: RION.

Bosker, Roel J. and W.H. Adriaan Hofman. 1994. School effects on dropout. A multilevel approach to assess school-level correlates of drop out of ethnic minorities. Tijdschrift voor Onderwijsresearch 19(1): 50-64.

Boudon, Raymond. 1974. Education, opportunity and social inequality. John Wiley: New York.

Bourdieu, Pierre and Jean-Claude Passeron. 1977. Reproduction in education, society and culture. Sage: Londen.

Bryk, Anthony S. and Yeow Meng Thum. 1989. The effects of high school organizations on dropping out: An exploratory investigation. American Educational Research Journal 26(3): 353-383.

Cairns, Robert B., Beverly D. Cairns and Holly J. Neckerman. 1989. Early school dropout: configurations and determinants. Child Development 60: 1437-1452. 
Centraal Bureau voor de Statistiek. 1987. Standaard Onderwijs Indeling 1978. Centraal Bureau voor de Statistiek: Den Haag.

Centraal Bureau voor de Statistiek. 1991. Schoolloopbaan en achtergrond van leerlingen: cohort 1989. Deel 1: instroom. Den Haag/Heerlen: Centraal Bureau voor de Statistiek.

Centraal Planbureau. 2006. Voortijdig schoolverlaten in Nederland: Omvang, beleid en resultaten. Centraal Planbureau, Den Haag.

Coleman, James S. 1988. Social capital in the creation of human capital. American Journal of Sociology 94: S95-S120.

De Graaf, Paul M. 1986. The impact of financial and cultural resources on educational attainment in the Netherlands. Sociology of Education 59: 237-246.

1993. 'Family background and educational attainment in the Netherlands for the 18911960 birth cohorts', In: Y. Shavit \& H-P. Blossfeld (red.), Persistent inequality: Changing educational attainment in thirteen countries. Boulder; London: Westview Press.

De Graaf, Nan Dirk and Paul M. De Graaf. 2002. Formal and popular dimensions of cultural capital: Effects on children's educational attainment. The Netherlands' Journal of Social Sciences 38(2): 167-186.

De Vries, Robert, Wolbers, Maarten and Rolf Van der Velden. 2003. De arbeidsmarktpositie van schoolverlaters en werkenden zonder startkwalificatie. Den Haag: Raad voor Werk en Inkomen (RWI)

De Wit, Walter and Hetty Dekkers. 1997. Drop-out of startkwalificatie. Omvang, achtergronden en gevolgen van voortijdig schoolverlaten in de eerste vijf jaren voortgezet onderwijs. Tijdschrift voor Onderwijsresearch 22(4): 211-227.

Dekkers, Hetty and Adrie Claassen. 2001. Dropouts-Disadvantaged by definition? A study of the perspective of very early school leavers. Studies in Educational Evaluation 27: 341-354.

Dekkers, Hetty. 2003. Voortijdig schoolverlaten. In: Voortijdig schoolverlaten. Alphen a/d Rijn.: Kluwer

DiMaggio, Paul. 1982. Cultural capital and school succes: The impact of status culture participation on the grades of U.S. high school students. American Sociological Review 47: 189-201. 
Driessen, Geert and Greetje van der Werf. 1992. Het functioneren van het voortgezet onderwijs. Beschrijving steekproef en psychometrische kwaliteit instrumenten. Groningen/Nijmegen: RION/ITS.

Ensminger, Margaret E. and Anita L. Slusarcick. 1992. Paths to high school graduation and dropout: a longitudinal study of a first-grade cohort. Sociology of Education 65: 95-113.

Finn, Jeremy D. and Donald A. Rock. 1997. Academic succes among students at risk for school failure. Journal of Applied Psychology 82(2): 221-234.

Goldsmith, Pat António. 2004. Schools' racial mix, students' optimism, and the black-white and Latino-white achievement gaps. Sociology of Education 77: 121-147.

Goldstein, Harvey. 1995. Multilevel statistical models. London: Edward Arnold.

Heard, Holly E. 2004. The life course of family structure and adolescent school achievement: Racial and ethnic differences. Paper presented at the Population Association of America 2004 meeting, Boston.

Hofman, W.H. Adriaan. 1993. Effectief onderwijs aan allochtone leerlingen, een empirische studie naar de invloed van school- en klasfactoren op de loopbaan van allochtone en autochtone leerlingen in het voortgezet onderwijs. Eburon: Delft.

Hout, Michael .1988. More universalism, less structural mobility; The American occupational structure in the 1980's. American Journal of Sociology, 93(6): 1358-1400.

Johnson, Monica Kirkpatrick , Crosnoe, Robert and Glen H. Elder, Jr. 2001. Students' attachment and academic engagement: The role of race and ethnicity. Sociology of Education, 74, 318-340.

Lamb, Stephen. 1994. Dropping out of school in Australia: Recent trends in participation and outcomes. Youth and Society 26(2): 194-222.

Marks, Gary N. 1998. Attitudes to school life: Their influences and their effects on achievement and leaving school. Australian Council for Educational Research: Camberwell.

Marks, Gary N. and Nicole Fleming. 1999. Early school leaving in Australia: Findings from the 1995 year 9 LSA Y cohort. Australian Council for Educational Research: Camberwell.

Ministerie van OC\&W. 1993. Een goed voorbereide start. Den Haag. 
Ministerie van OC\&W. 2006. Bestel in Beeld 2006. Den Haag.

McLanahan, Sara and Gary Sandefur. 1994. Growing up with a single parent. Waht hurts, what helps? Harvard University Press: Cambridge.

Ní Bhrolcháin, Máire, Chappell, Roma, Diamond, Ian and Catherine Jameson. 2000. Parental divorce and outcomes for children: Evidence and interpretation. European Sociological Review 16(1): 67-91.

O'Brien, Maeve. 2003. Girls and transition to second-level schooling in Ireland: 'Moving on' and 'moving out'. Gender and Education 15(3): 249-267.

Rumberger, Russell W. 1983. Dropping out of high school: The influence of race, sex and family background. American Educational Research Journal 20(2): 199-220.

-----. 1987. High school drop-outs: A review of issues and evidence. Review of Educational Research 87(2): 101-121.

-----. 1995. Dropping out of middle school: A multilevel analysis of students and schools American Educational Research Journal 32(3): 583-625.

-----. 2000. The distribution of dropout and turnover rates among urban and suburban high schools. Sociology of Education, 73, 39-67.

Shavit, Yossi and Hans-Peter Blossfeld. 1993. Persistent inequality: Changing educational attainment in thirteen countries. Boulder; London: Westview Press.

Smerdon, Becky A. 2002. Students' perceptions of membership in their high schools. Sociology of Education, 75, 287-305.

Snijders, Tom A.B. and Roel J. Bosker. 1999. Multilevel analysis. An introduction to basic and advanced multilevel modeling. London/Thousand Oaks/New Delhi: Sage.

Traag, Tanja, Van der Valk, Johan, Van der Velden, Rolf, De Vries, Robert and Maarten Wolbers (2004), Leren Loont! De overgang van school naar werk voor leerlingen van het VOCL '89, ROA-R-2004/6, Maastricht: ROA + CBS.

U.S. Department of Education. National Center for Education Statistics. 2001. Fathers' and others' involvement in their children's schools by family type and resident status, NCES 2001032, by Christine Winquist Nord and Jerry West. Washington, DC. 
Van der Slik, Frans W.P., Geert W.J.M. and Kees L.J. De Bot. 2005. Ethnic and Socioeconomic Class Composition and Language Proficiency: a Longitudinal Multilevel Examination in Dutch Elementary Schools. European Sociological Review 2006 22(3):293-308

Van der Velden, Rolf, De Vries, Robert, Wolbers, Maarten and Patrick van Eijs (2002), De waarde van een startkwalificatie, ROA-R-2002/14, Maastricht.

Van der Werf, Greetje P.C., Lubbers, Miranda J. and Hans Kuyper. 2002. Het interne rendement van het voortgezet onderwijs. GION: Groningen.

Veendrick, Laurenz, Tavecchio, Louis and Jeannette Doornenbal. 2004. Jongens als probleem. Pedagogiek 24(1): 12-22

Voelkl, Kristin E. 1995. School warmth, student participation and achievement. Journal of Experimental Education 63(2): 127-138.

Drs. Tanja Traag works as a researcher at Statistics Netherlands, at the Statistical Analysis Department of the Division of Social and Spatial Statistics in Heerlen. Her current research interests include the transition from school to work, especially short and long term effects of early school-leaving.

Prof. dr. Rolf van der Velden is head of the Division Education and Occupational Career at the Research Centre for Education and the Labor Market (ROA), Maastricht University. He has published on many studies in the field of education, training and labor market. His current research interests include international comparisons in the transition from school to work, competence development during education, the long term effects of education on occupational careers, overeducation and skills mismatches and the effect of generic and specific competences on labor market outcomes. 